\title{
RESULTS OF FENESTRATION SURGERY FOR OTOSCLEROSIS
}

\author{
By
}

S. TAKAHARA, S. SUMIDA, H. FUJIMORI AND N. NAGAO

From the Depertment of Oto-Rhino-Laryngology Okayama University

Medical School (Director: Prof. S. Takahara)

During the two-year period from 1955 to 1957, the number of ears that we had been able to diagnose as clinical otosclerosis, amounted to 38 ears out of 21 cases examined in our department, and out of them only 15 ears received fenestration.

In the postoperative hearing test of these 15 fenestrated ears, all of them showed improvement, although one case developed bony closure of the new fenestra, which was corrected by second surgery. Seven ears out of ten that we could follow up for more than one year after fenestration, restored the practical level of $30 \mathrm{db}$ in the average speech range. Ten ears out of $11 \mathrm{~A}$-type ears restored the level of $30 \mathrm{db}$. In $\mathrm{C}$-type ears, only one out of 4 ears restored a hearing improvement, reaching to the level of $30 \mathrm{db}$.

In average, the ears that had shown preoperative level of $53 \mathrm{db}$ restored $24 \mathrm{db}$, reaching to the level of $29 \mathrm{db}$. Which is equal to the anticipated value obtained by Carhart's method preoperatively.

Moreover, postoperative labyrinthitis was seen in 5 minimal type ears, 10 mild type and one moderate type in the classification described by Shambaugh and Takahara. It is interesting to note that minimal serous labyrinthitis was seen in A-type and also the most of A-type restored the practical level of hearing. In the case with complete fixation of stapes, there was an average hearing improvement of $25 \mathrm{db}$ after operation, while an average improvement was $17 \mathrm{db}$ in the cases with incomplete fixation, showing that the cases with complete fixation were greatly improved by the operation.

\section{耳硬化症に対する内耳開空術の聴力成績}

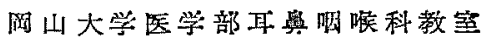

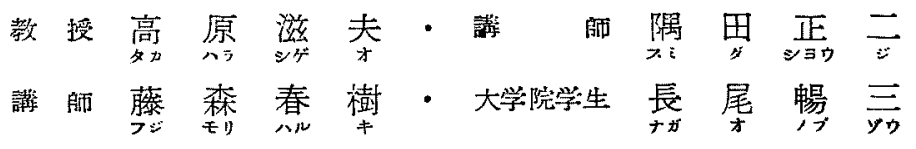

耳缩化症例に我国に抬いては極るて少く，本症に対す る内耳開空術の症例も柏戸，堀口，後藤(修)，橋本の諸 氏が各々数例を報告しているのみで，その詳細な成續は なく。欧米のそれに較べ諴に蔫々たるものである。岡山 大学医学部耳奥科教室において昭和 30 年 7 月より 32 年 6 月迄の 2 年間に耳硬化症と診断し得た 21 人 38 耳の 中，内耳開空術を行つたものは15耳に過ぎない。この 数字はさつやかなものであるが，本邦に和汓る内耳開密 術の成績として，こつに報告し諸賢の御批判を仰ぐもの
である・

\section{I. 手街の適応}

まず耳硬化症としての診断が必要である・これには既 往に和いて中耳炎に罹患したことがなく，自覚的には進 行性の藉聴を訴光，他覚的には鼓膜，中耳，耳管になん ら異常が無く，聴力検査では伝音系障碍を呈して和り。 気導曲線と骨導曲線との間に $20 \mathrm{db}$ 以上の距りを示し ているもので, 更に音农による Weber, Rinne, Gellé 氏検查, Audiometer に上る新 Gellé 氏法, 補充現象 
(Recruitment)，恩地氏 耳栓骨䆃検查:，語音明 瞭度检 查，語音了解度検查:等により神経性難聴と鑑別されたも のである.

以上の如くして埥断された耳硬扎症例もこてのすべてが 關空術の適応とはなり得ない，即ら耳硬化症の難聴は鐐 骨强直に上る伝音障淂と，多くの晹合とれに伴ら螖牛神 経の二次的変性による感音障碍との2つの要素より成 る.このうち開空術によつて修復し得るの标伝暗障碍の

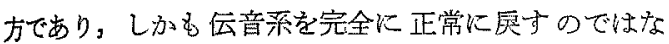
く，開空術により新しい音の伝導路を作り，狇空を介し て音を值接内耳に電ふに過ぎない.そのため鼓膜と耳小

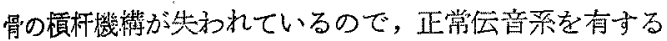
るの小聴力に比し約 $25 \mathrm{db}$ の聴力嘪失が活る。往つて

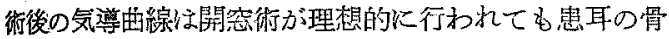
尊曲䠌より $25 \mathrm{db}$ 下方にあり，そ九以上に持ら来たせな いこつに述べる骨導曲線は Carhart の方式に㱜い。

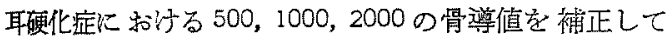
得た真の骨導徝のことを意味している。

このことよりして，開空術は耳硬化应と䛦泍し得たも ので，螎牛神経の变性が最小で，鐙骨の強直による伝音 障碍の最大の場合，即ら骨尊曲線が正常に近く骨尊と気 導曲線の距りが大きい程手術適応となり，通常 $40 \mathrm{db}$ 以 上の距りを有するるのが手術適応に入ることつなる。

そこで開密術の適応は Audiometer 及び音攴検查等 により鐙骨の強直状態と蝸牛神経の变性の程度に従つて 次の如く分類される。

\section{A 型：手衍に理想的庭例}

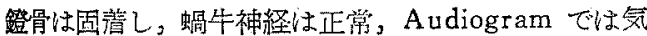
尊曲線は会話音域で 40〜60db の損失，学莩は Carhart の補正で正管籍团にある。

予後は80〜85\%の8のが聴力提失 $30 \mathrm{db}$ 以内以趭L， 補德器を要女ず会話可能。

$\mathrm{B}$ 型：理想的に非ざるも手術適する症例

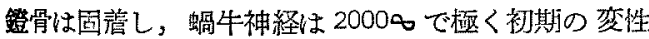

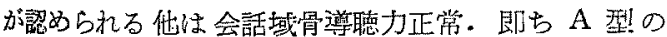

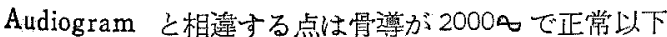
にあるが 500,1000هは正常籍围にある。

予後は $50 \%$ の人が $30 \mathrm{db}$ 以内の咕力損失で補聴器を 要せずして会話可能.

$\mathrm{C}$ 型：手術の效果の疑わしいもの

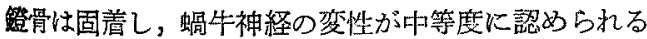
もの. Audiogram で気導は会話音域で 70〜90db の高 度蜼㯖を呈し，骨導は会話音域の全般にわたり正常以下
にある・

予後は 5〜10\%のものが $30 \mathrm{db}$ 以内の㯖力損失で 補 聴器を要也ずして会話可能.

このようにして A， B，C の3型に術前の適応を分類 した場合，我々の手術症例では A 型11耳，B型1耳， C 型 4 耳之なつている.

\section{II. 手術術式}

各症例と\& Shambaugh の術式に従つて局所磨醉下 に内耳開密術を行つた。即ち Shambaugh の皮切に上

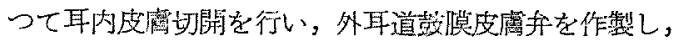
Attico-antrotomy の術式で最初から影様洞，上渻室を

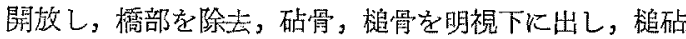
関節をはずし砧骨を除志，更に桘骨頭部をその项部より 切断す，次いで水平半䙺管，上半梘管前端を浮昨引り

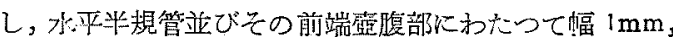
長さ $3.5 \mathrm{~mm}$ 程度の新密を手術用㩆钽鏡下に Burr で周 骨して作る。新密作彗に際しては Enchondralization を十分に行い，Shambaugh の持続濳涹法を応用して血 液，骨帉の外リンパ腔内への迷入を防いだ.かくして開 空部に外耳道骨膜皮篟手を十分土迫密着せしめた. 又本 手衍にあたつては厳重な無菌㩭作の下に行つたが，これ は後に述べる迷路炎発生予防の上からも㯖要なことであ ると考光る。

\section{III. 術後の聴力結果総括}

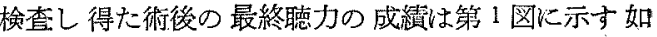
く，幸いにも聴力は術後いずれる改善され，墨化した例 はないこえれら全症例を平均して見ると，術前聴力平均 $53 \mathrm{db}$ であつたのが，術後 $24 \mathrm{db}$ の增進をきたし：平均

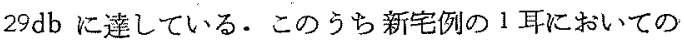
み術後 3週間目に一旦 $28 \mathrm{db}$ に迄恢復していた聴力が， 術後! 力月目頃上り次第に下降し始め，6力月後には術前

第1图 Fenestration と最終聴力

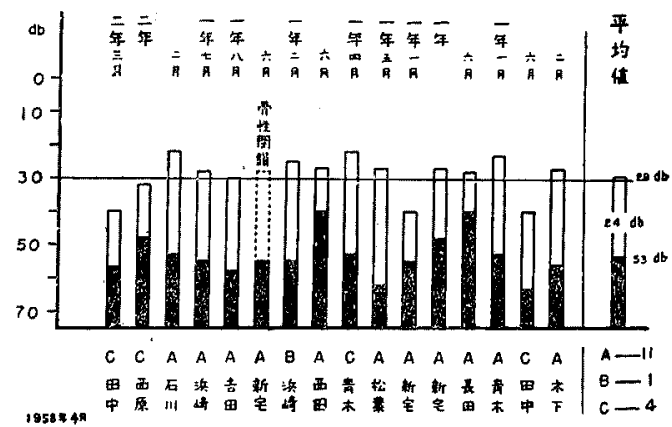


の聴力に復帰した.この症例は再手術を行い聴力を $55 \mathrm{db}$ より $40 \mathrm{db}$ 飞迄恢復せしめ得たが，その再手術の際， この聴力の下降が開空部の骨性閉鎖に基づくものである 事を磪認し得た。

このうち術後 1 年以上を経過し，その遠隔成績を検查 し得たものは 10 耳で，そのうち 2 耳は 2 年を越穴てい るが，その成結は第 1 表の如く，会話音域の 平域値が $30 \mathrm{db}$ の実用値以内にあるものは 7 耳 $(70 \%) ， 30 \sim 40$ $\mathrm{db}$ のものは3耳となつている，又術後 1 年に達しない 他の 5 耳及び新宅例の初回手術例を含めた全症例につい て見ると，16耳中 11 耳 $(73 \%)$ が会話音域の 平均鳁力 が 30db 以内に改善されて打り、30 40db にあるもの 4 耳， 1 耳は前述の如く骨性閉鎖により術前聴力の $55 \mathrm{db}$ そ止まつている.

第 1 表 手衍成綪の總括

泪後 1 年以上経過の6の 10 例

$$
\begin{aligned}
& 7 \text { 例— } 30 \mathrm{db} \text { 以丙 } \\
& 1 \text { 例- }-32 \mathrm{db} \text { loss } \\
& 2 \text { 例 }-40 \mathrm{db} \text { loss }
\end{aligned}
$$

全例 16 例（再手酒例含心）

11 例- $30 \mathrm{db}$ 以丙

1 例— $-32 \mathrm{db}$ loss

3 侧— $-40 \mathrm{db}$ loss

1 例— $55 \mathrm{db}$ (微前值一骨性閉鑹)

これを術前における手術適応型について調べると，第 2 表に示寸如 $<，$ 術前の適応 A 型 11 耳中 10 耳 (91\%) が $30 \mathrm{db}$ 以内に改善されて和り，C 型では 4 耳中 1 耳 (25\%)のみが 30db 以内に聴力の增進を認めている. またその聼力增進度から見ると，A 型が平均 $24 \mathrm{db} の$ 增進であるのに対し，C 型では平均 22db の增進を呈 しこれらの点から考えて A 型の方が手術結果が明ら か優れていることを示している。

\begin{tabular}{|c|c|c|c|c|c|c|}
\hline 刑 & 鿉 & 術 & 後 & 㯖 & 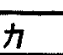 & mitan \\
\hline \pm & (j) & 䟭坞值 & & & & \\
\hline A & 11 & $28 \mathrm{db}$ & $\left(P_{1},(x)\right.$ & 1 & & $+24 \mathrm{db}$ \\
\hline B & 1 & $25 \mathrm{db}$ & 1 & & & $+30_{d b}$ \\
\hline C & 4 & $33 \mathrm{db}$ & 1 & 3 & & $1+22 \mathrm{db}$ \\
\hline
\end{tabular}

第 2 表

A B C 型と術徒的揌力

IV. 術後迷路炎

殆どの症例において開空直後一旦聴力が增進するが， 次いで発来する將液性迷路炎のために種々なる程度の聴 力下降が起る.この下降は通例術後 4 日目から 7 日目迄 の間に著明で，術後10日目頃から急速飞恢復し始め， 通例 1 力月後, 稀に 6 力月後に聴力恢復の頂点に達寸 る.この將液性迷路炎の経過を Shambaugh と高原は 第 2 図に示す如く次の 3 期に分けている.

1. 初期㯖力恢復期 Initial Improvement

2. 術後性聴力下降期 Postoperative Depression

3. 最後的恢復期 Final Improvement

また迷路炎の程度を第 3 表の如く 5 型に分頑してい る. 即ち微小型 (minimal) 及び軽症型 (mild) は手術 直後に獲られた聴力に迄恢復するものであるが，中等型 (moderate) は術前よりは聴力はよいが，術直後の聴力 迄恢復せず，殊汇高音の恢復の要い 群である．重定型 (severe) は炎症高度で聴力は下降した 儘全く㤥復を示 さず，術後聴力が術前より悪化しているものである・化 膿型（purulent）は化膿性迷路炎をきたし，蝸牛は元 の機能を失い醷に至つたものである。

我々の手術症例ではこの分類に従うと微小型 5 例, 俥 症型 10 例，中等型 1 例で，幸いにして重症型，化膿型 は見られなかった。

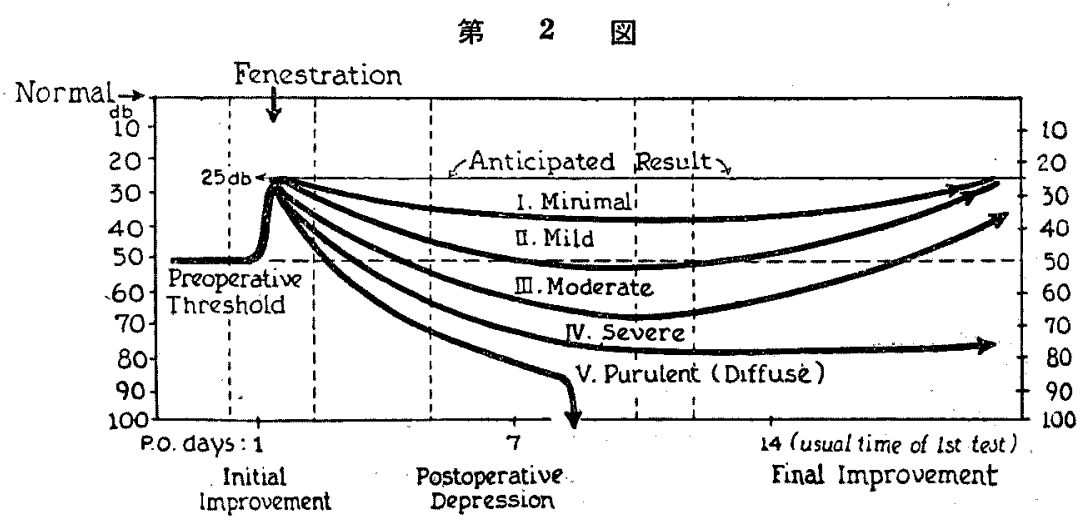


第3表 Classification of Postoperative Labyrinthitis

A. Sterile serous Labyrinthitis localized to fenestra

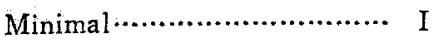

B. Sterile diffuse serous labyrinthitis

Mild ................................ II

Moderate......................... II I

Severe ............................ IV

C. Diffuse pururent labyrinthitis.....V

$$
\text { 第 } 3 \text { (a) }
$$

A Case Minimal Lobyrinthitis Namo 松菜 9 Age 40 Dato 31. 11 . 8 L. Fenestration

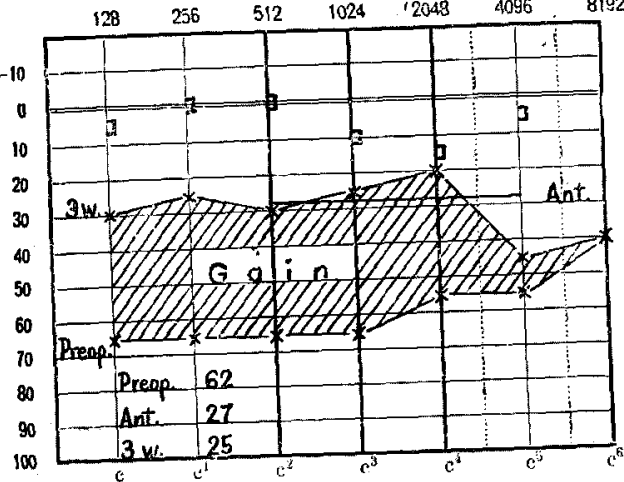

$$
\text { 第 } 3 \text { 图 (b) }
$$

A Case : Minimal Labyrinthitit
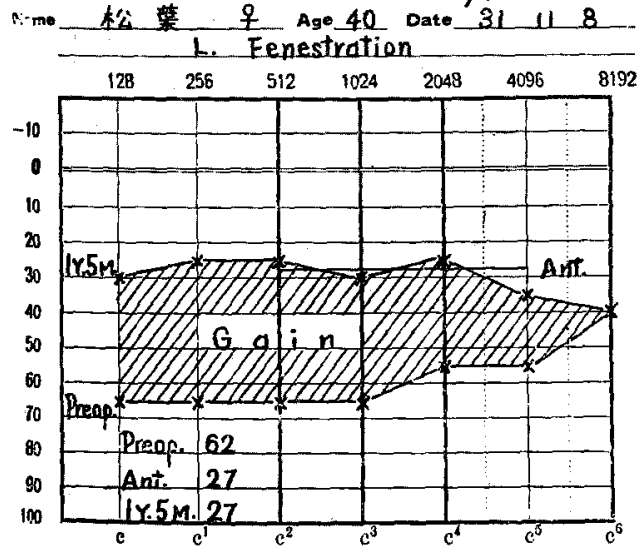

この迷路炎各型の代表的症例を示すと，做小型は第 3 图、に示寸術前適応 A 型の松葉例で，これは術後了週 間目の聴力检查で高音，低音共に最初から術後予想閔値

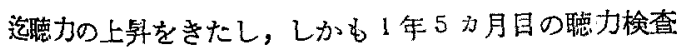

においてるこれが保たれている(第3园 b): 軽症型は 第 4 図の術前適沁 B 型の浜崎例で，これは術後3週間 目の聴力検查で低音域は上界しているが，高音域の周波 数では低下を呈し高音陵碍の像を示している。しかしそ

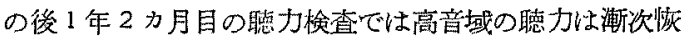
復してきた。中等型性第 5 図の術前邀㐫Ｃ型の由中例 の如きもので，術後 3 週間目の聴力の上昇は少く，高音 域聴力はさしろ低下し，術後 2 年 3 力月目の㯖力に蛙い ても高音域性筑として恢復を見なかっつたか，低音域で は鳃力の上昇家認めている。

\section{第 4 图}

B Case : Mild Labyrinthitis

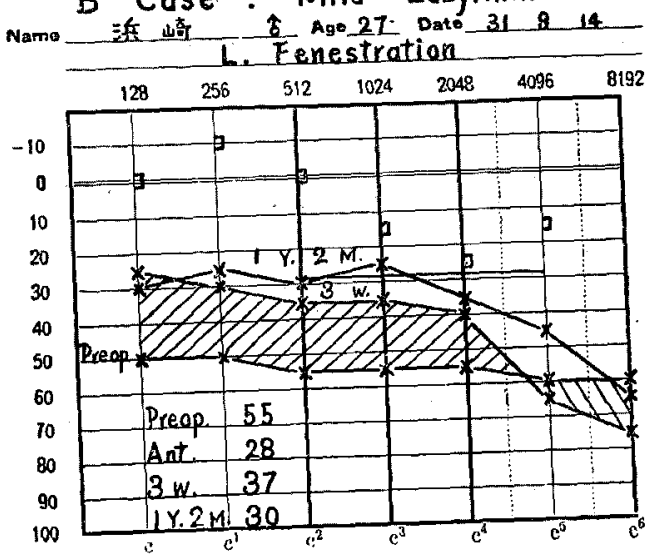

第 5 图

C Case: Moderate Lobyrinthitis

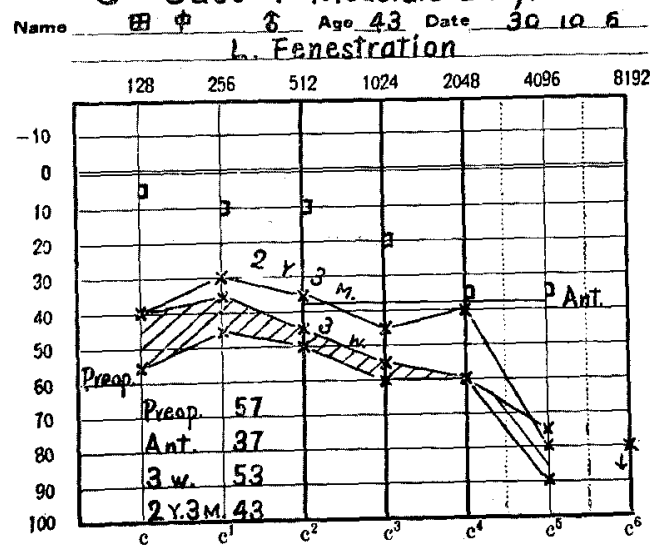

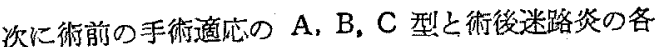
型との関係を見ると，第 4 袁の如く骨導值正常で螖牛神 経の健在を示扵 $\mathrm{A}$ 型11 例中，衍後迷路炎の微小型5 
例，轻症型6例であるに比し，螖牛神経の変性を゙伴なつ ている C 型では, 軽症型 3 例, 中等型1 例となつてい る・これを逆に云えば我くの最す希望する微小型の迷路 炎は全部 $\mathrm{A}$ 型のるのに片け見られているという事であ つて，これは前述の $\mathrm{A}$ 型のものに拈いて聴力恢復度の 上い事と相侯つて注意を惹く所であると考允られる。

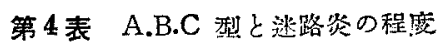

\begin{tabular}{|c|c|c|c|c|}
\hline \multicolumn{2}{|c|}{ 型 } & Minimat & & Moderate \\
\hline A & 11 & 5 & 6 & \\
\hline$\theta$ & 1 & & 1 & \\
\hline c & 4 & & 3 & 1 \\
\hline
\end{tabular}

な彻開空に伴ら前庭症状としては軽度の矓最を術後数 日訴えた例が軽症型に 2 例，中等型に 1 例認められ，術 後 2 日間覀心，嘔吐孛きたした例が軽症型に 2 例あつ た。いず机もこれら症状は尃後1違以内に消失してお。 り，步行障碍をきたすよらな症例は見られなかつた。

\section{V. 術前予想閾值と術後聴力}

術前の予想閾值については手術適応でる述べてある如 く，500，1000，2000の各偽波数に括ける骨導值に対し， Carhart の補正值を隶めて予想閥值を算定した：即ち $500,1000,2000$ の各周波数の骨導值に各心 $-5,-10$, - 15db の補正を行い，その真の骨㧘平均值之推定する ものに，鼓膜と耳小骨の槙杆機洅消夫による聴力損失 $25 \mathrm{db}$ を加えたものをるつて現わしてある。

この予想閾值と実際の術後聴力之の 関係を見ると第 6 図の如くなり，西原，松藮例を除いては10例が $\pm 5 \mathrm{db}$ の篹囲内にあり，4例が 士5〜10db の誤差範囲内にあ り，予想間值は術後実蹬值之極めて接近した值を示し， これを平均値で現わすと図の右踹の如く，偶然ながら予

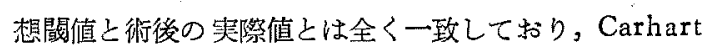

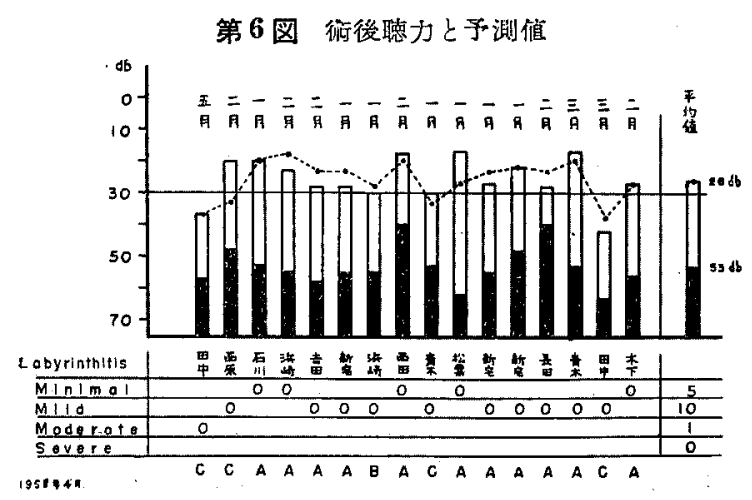

による予測值の信頼度は極めて満足すべきものであるこ とを示している。

\section{VI. 鐙骨可動性亡術後聴力}

鐙骨が完全醮直の場合で神経変性のないものが手術の 最適応であることは既に述べだ通りである。從つて手術 中に手術用顕微鏡下に視野を拡大し，鐙骨の可怔性を消 息子で估細に検查するのみならず，鐙骨の强直が炎症炕 由来していないかの点についても礁かむねばならぬ.我 我の症例では鐙骨の完全強直は 15 耳中 12 耳で，不完全 強直は 3 耳であつた。こ学ら完全強直耳の聴力增進は平 均 $25.6 \mathrm{db}$ であるのに比し、不完全強直のものでは平均 $17.3 \mathrm{db}$ である.これは不完全強直のものでは㯖力が十 分低下していない、眭期沲術された〉め，その恢復度が 少なからたという事の他隹に，既に手術により中断されて いるが，鐙骨の可動性を介し，多少の内耳内への音层導 が存在し、これが新空を介して迷路液中に進入する音波 と相于浟して勢力の相殺を起す事も考えられる.

これら各定例は手術所見に沶いて全く炎症所見を欠 き，しか子鐙骨の可動性が障碍されている事が礁かめら

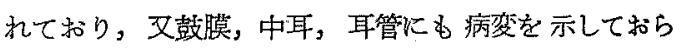
ず，乙かる手術後，外国の諸学者の指摘する如き明らか な聴力の上昇をきたしている点等より，末だ日本人の耳 硬化症の組織学的証明はないが，钞くとも臨床的耳硬化 症は我々日本人間にる存在するものであると推定して差 交觉ないのと考觉る。

\section{結 語}

昭和 30 年 7 月より炤和 32 年 6 月迄の 2 年間に岡山 大学医学部耳番科教室で耳硬化症に対する内耳開空術を 行つた 15 耳につき術後聴力検查を行つた結果，全应例 に拉いて聴力の改善を認め，この中 1 耳は開空部の骨性 閉鎖をさたしたが再手術により再び聴力改善を見た。術 後1 年以上を経過して遠隔成結を検し得た 10 耳中 7 耳 が 30db 以内の実用值を獲ている。 またこれを術前 の手術適応型について見ると，A 型 11 耳中 10 耳が $30 \mathrm{db}$ 以内に改善され，C 型では4 耳中 1 耳の及各: $30 \mathrm{db}$ 以内の聴力を獲ている. 全症例を平均してみる と術前 $53 \mathrm{db}$ であつたのが術後 $24 \mathrm{db}$ 改善し，29db に達しているがっこれは術前の Carhart の予測値の 平均値と偶然にも一致している.

術後迷路炎ではShambaugh，高原の分類による微 小型 5 耳，軽症型 10 耳，中等型 1 耳で; 微小型忖 べて術前適応 $\mathrm{A}$ 型のものつみに見られ，A 型聴力

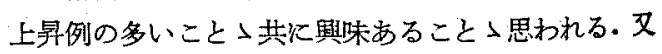


蹬骨の完全强直例では 平均 $25 \mathrm{db}$ の聴力上界があり， 不完全强直例では平均 $17 \mathrm{db}$ の上犁で，完全强直例に行 った方が聴力上最度のよい事を示している。

以上より耳硬化症に対する内耳開空術では術前の蝸牛 神経の変性程度いかんが手術結果の良否に密接に関係し ていることが判り，徒つて手術刘象としては蝸牛神経の 变性が少く，しかす鐙骨の完全强直しているものが最も 好むしいと云兄る。しかしこの蜡牛神経の障碍程度を判 定する事は仲々難加しい問題であつて，我くの倬かな経

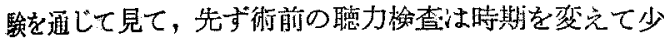

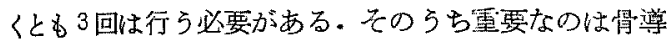
検查で, Audiometer による他に，音必による検睢も古 典的ではあるが試みる必要がある。またこの他 Jerger 氏法炕よる Recruitment の応用，Audiometer 使用 によるGellé 氏法，恩肔氏法もこの点の判定に当り有 用で，これら諸検查家交じえて，総合的に螎牛神経の状 態をできるだけ正磪汇判定し，本手術の適応を決めるこ 之が大切である.

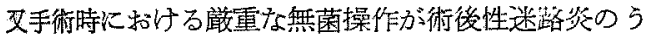
ち，重应型，化膿型を予防し得ていると考えるとき，本
手術における消毒の問題も注意すべきことであると考え る.

\section{菱交献}

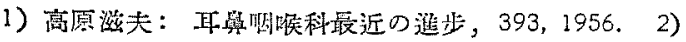
Shambaugh, G.E. \& Takahara, S.; Acta otol. Supp. $123,1955.3$ 3) Shambaugh, G.E. \& Carhart, R.: A.M.A. Arch. of Otol. Vol. 54, 699, 1951. 4) Davis, H. \& Walsh, T.E.: Laryng. Vo!. 60,

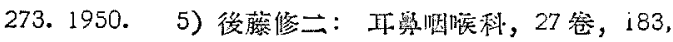

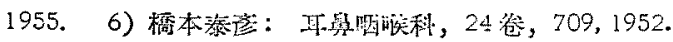

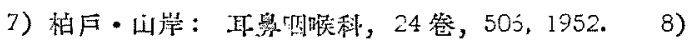

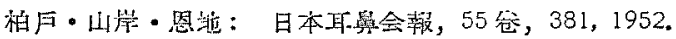

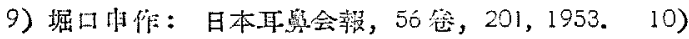

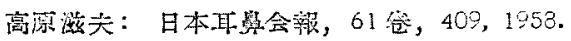

(本諭交の姴旨过妿和 32 年 4 月, 第5 59 回日

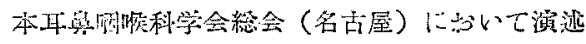
(林)

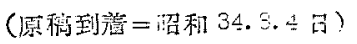

